\title{
Title of Manuscript
}

Review article: Effectiveness of Ultra-Brief Interventions in the Emergency Department to

Reduce Alcohol Consumption: a systematic review

\section{Author List:}

Dr. Rosemary A. McGinnes, BSc (Hons), Grad Dip Epi Biostats, DHSc

$=$

Dr. Jennie E. Hutton, MBChB, MPH, CCPU

Dr. Tracey J. Weiland, MPsych, PhD,

Professor Daniel M. Fatovich, MBBS, PhD

Associate Professor Diana Egerton-Warburton, MBBS, MClinEpi, MPH

\section{Author contributions:}

DEW conceived the study and obtained funding. RMcG, DEW and DF developed the Protocol.

RMcG conducted the search and acquired the data. RMcG, JH, TJW and DEW participated in the analysis and interpretation of the data. RMcG and JH drafted the article, tables and figures and all authors contributed substantially to its revisions. RMcG takes responsibility for the paper as a whole.

Author Affiliations:

Rosemary A. McGinnes, DHSc

School of Clinical Sciences at Monash Health, Monash University, Melbourne, Victoria,

Australia.

This is the author manuscript accepted for publication and has undergone full peer review but has not been through the copyediting, typesetting, pagination and proofreading process, which may lead to differences between this version and the Version of Record. Please cite this article as doi: $10.1111 / 1742-6723.12624$

This article is protected by copyright. All rights reserved. 
Jennie E. Hutton, MBChB, MPH, CCPU

Emergency Department, St Vincent's Hospital, Melbourne, Victoria, Australia.

Tracey J. Weiland, MPsych, PhD,

Emergency Practice Innovation Centre, St Vincent's Hospital, Melbourne, Victoria, Australia

Daniel M. Fatovich, MBBS, PhD

Emergency Medicine, University of Western Australia, Perth, Western Australia,

\section{Australia}

Diana Egerton-Warburton, MBBS, MClinEpi, MPH

Monash Medical Centre Emergency Department, Monash Health, Melbourne, Victoria,

Australia

School of Clinical Sciences at Monash Health, Monash University, Melbourne, Australia.

\section{Corresponding Author:}

Rosemary A. McGinnes,

School of Public Health and Preventive Medicine

Monash University

The Alfred Centre

99 Commercial Road

Melbourne VIC 3004

This article is protected by copyright. All rights reserved. 


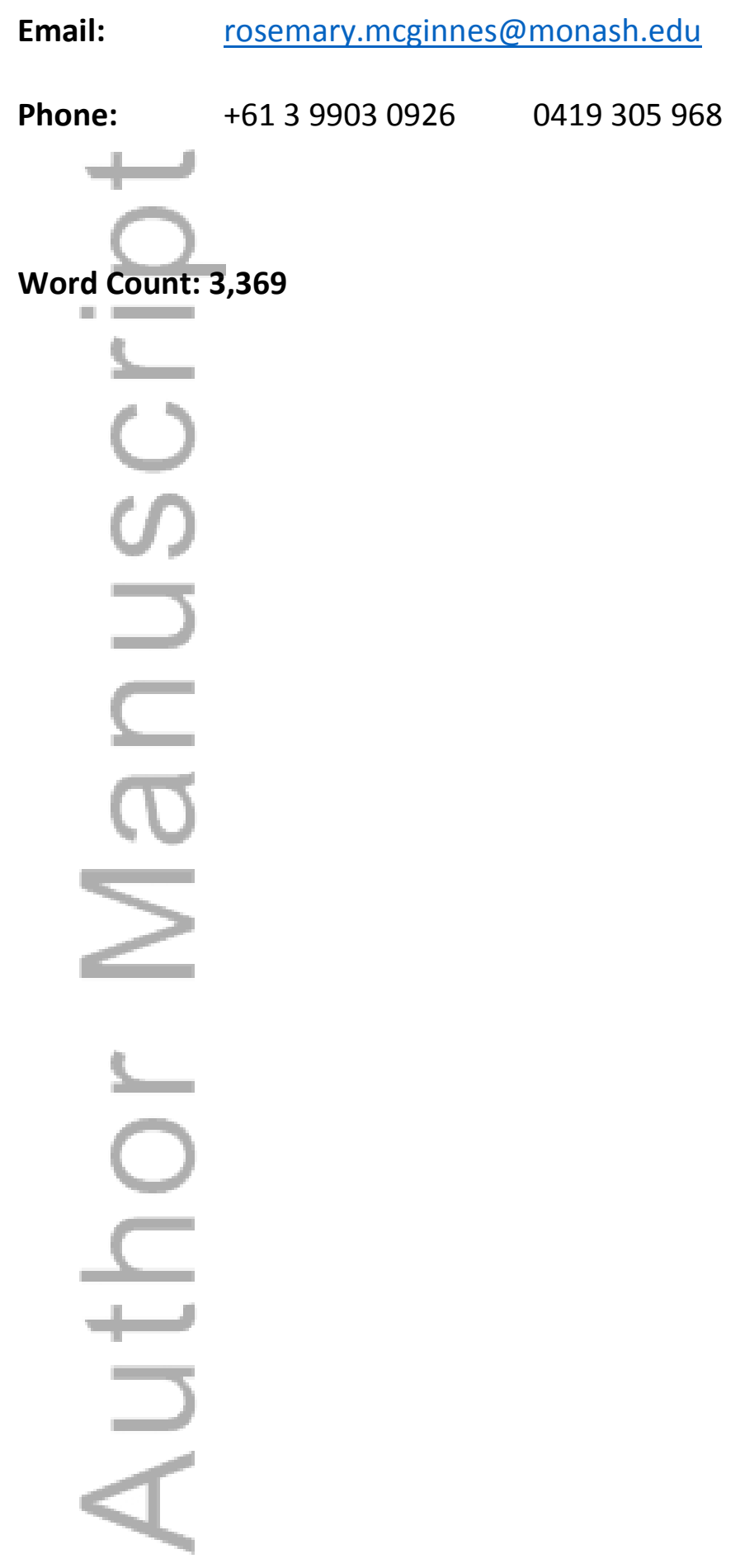

This article is protected by copyright. All rights reserved. 


\section{Abstract}

To assess the effectiveness of ultra-brief interventions (ultra-BI) or technology-involved preventive measures in the emergency department (ED) to reduce alcohol harm and risky drinking. Medline, Embase, PsycINFO, CINAHL and EBM Reviews were searched for articles published between 1996 and 2015. Randomised controlled trials and quasi-randomised trials, which compared an ultra-BI with screening, standard care or minimal intervention for adults and adolescents at risk for alcohol related harm presenting to an ED were included. Outcomes of interest were frequency of alcohol consumption, quantity of alcohol consumed, binge drinking and ED representation. Thirteen studies (nine single-centre and four multi-centre) were included. Six studies showed a significant reduction in the quantity consumed with intermediate effect size at three months $(\mathrm{d}=-0.40)$ and small effect size at 12 months $(d=-0.15)$. Two studies showed a significant reduction in binge drinking with small effect size at three months $(d=-0.11)$ and 12 months $(d=-0.09)$. No studies showed an effect on frequency of alcohol consumption or ED representation. Heterogeneity in study design, definition of risky, harmful or hazardous alcohol use, intervention types, outcomes, outcome timeframes and outcome measures prevented the performance of quantitative meta-analysis. Despite its limited effectiveness in reducing alcohol use in the short-term, with the large number of people attending EDs with risky drinking, the use of an effective ultra-BI would have the potential to have a measurable population effect.

\section{Key words}

alcohol harm, brief intervention, emergency department, systematic review

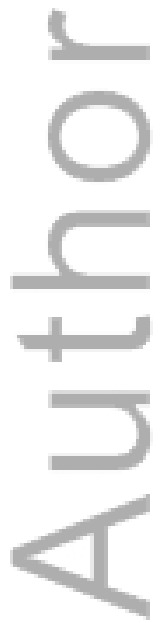

This article is protected by copyright. All rights reserved. 


\section{Introduction}

Alcohol is major cause of death and disability, transcending international boundaries. An estimated 3.3 million people die annually of alcohol-related harm worldwide. ${ }^{1}$ This represents $5.9 \%$ of all deaths and translates to $5.1 \%$ of total disability-adjusted life years. ${ }^{1}$

Patients showing evidence of alcohol harm, both acute and chronic, are more prevalent in the Emergency Department (ED) population than in the general population. ${ }^{2}$ Recent data show that $14 \%$ of patient presentations to Australian EDs were alcohol-related. ${ }^{3}$ ED patients may be more amenable to an alcohol harm related intervention, particularly those who can attribute their attendance to alcohol, a concept termed 'the teachable moment'. ${ }^{4}$

The World Health Organisation (WHO) recognise the ED population to be an at-risk group that should receive alcohol "Screening Brief Intervention and Referral to Treatment" (SBIRT). ${ }^{5}$ In the US, since 2007, it has been mandatory for all level 1 Trauma Centres to offer SBIRT to all patients. ${ }^{6}$ A recent survey of Australasian Emergency Physicians indicates broad support for public health and health promotion in ED, impeded by significant barriers including lack of resources and time. ${ }^{7}$

While evidence exists for the effectiveness of Brief Interventions (BIs) for alcohol problems in the inpatient and primary care settings ${ }^{8}$, it is unclear how this translates to the emergency department setting. ${ }^{9}$ The demand of the ED service commitment and introduction of time based performance targets makes lengthy interventions by the ED clinicians unfeasible. Ultra-Bls of less than 10 minutes duration or using technology ${ }^{10}$ may offer a pragmatic approach overcoming barriers that clinicians have identified. ${ }^{7}$

Over 7.8 million people attend EDs in Australia and New Zealand annually. ${ }^{11,12}$ With research demonstrating that ED patients want to receive preventive health messages ${ }^{13}$ this large cohort gives ED interventions a high potential reach and means that even interventions with low to moderate effectiveness might have impacts on a large population. $^{14}$

The objectives of our review were to identify preventive health interventions in the ED setting for alcohol harm and to determine which preventive health interventions of ten minutes or less or involving technology are effective in reducing harmful or risky drinking. We aimed to describe the characteristics of the effective interventions and to identify any feasibility issues or barriers to the introduction of preventive health interventions in Emergency Departments.

\section{Methods}

A systematic review and narrative synthesis was conducted and reported according to the PRISMA Statement. ${ }^{15}$ Study design was informed by the Cochrane Collaboration. ${ }^{16}$ The protocol for this review was registered with PROSPERO 2014:CRD42014015322 ${ }^{17}$

\section{Data sources and search strategy}

An electronic search was conducted on Ovid Medline (1946 - Present) and adapted for Embase (1980 - Present), PsycINFO (1987 - Present), CINAHL (1937 - Present) and all EBM Reviews including the Cochrane Central Register of Controlled Trials (CENTRAL) and DARE (Database of Abstracts of Reviews of Effectiveness) databases. 
Medical subject heading search terms and text or keywords associated with the concepts of emergency treatment and harmful or heavy alcohol use were used (Table 1) and bibliographies of included articles were scrutinised for additional references. Limited to studies published since 1996, the search was run on 19 January 2015. No limits were applied for language and foreign papers were translated.

\section{Study selection}

One reviewer (RM) assessed the eligibility of retrieved papers by screening the titles and abstracts for relevance. Two independent reviewers (RM, JH) assessed selected full-text papers for inclusion and exclusion criteria. Disagreements were resolved by consensus, with a third reviewer (DEW).

\section{Inclusion criteria}

Articles that described an intervention which included screening for alcohol use, intervention by means of feedback, negotiation and goal setting, provision of information (pamphlet, computer or phone) and referral for treatment where clinically appropriate for adults and adolescents with either at-risk drinking behaviour, dysfunctional drinking patterns, or symptoms of an alcohol-related disorder attending an ED were included. Interventions were carried out by a physician or a member of the physician's multidisciplinary team, a member of the allied health team or a research team. Control groups received screening only, assessment only or minimal intervention which included the provision of written information or standard care. For the purpose of this review an ultra-BI was defined as any face-to-face interaction of ten minutes or less or any non face-to-face intervention involving technology.

Outcomes, measured or self-reported, included change in the frequency of alcohol use, quantity of alcohol consumed, including binge drinking, or change in the frequency of ED representation and could occur over any time period.

Randomised controlled trials (RCTs) and quasi-randomised trials evaluating interventions in the ED addressing alcohol-related harm were included.

\section{Exclusion criteria}

Studies that included patients attending a primary healthcare provider, admitted to hospital, locations in addition to the ED (unless ED numbers could be clearly identified) or describing interventions for problems in addition to those for alcohol misuse (unless interventions and outcomes could be clearly differentiated) were excluded.

\section{Data extraction and quality assessment}

Data were extracted independently $(\mathrm{RM}, \mathrm{JH})$ ) using a standardised, pre-piloted form based on the National Health and Medical Research Council guidelines ${ }^{18}$ modified from one previously used ${ }^{19}$ and cross checked for accuracy

Information was extracted from each included study on: (1) study characteristics including target population, treatment setting, location of the study and eligibility criteria; (2) patient recruitment including number of patients, recruitment processes and treatment and control conditions and follow-up rate; (3) intervention details including intervention goals, intervention delivery, intervention duration, measurement time points, setting and content 
and (4) outcome measures including frequency of alcohol use, quantity of alcohol consumed, including binge drinking, or change in the frequency of ED re-presentation.

Risk of bias for included studies was assessed independently by RM and JH according to the Cochrane Methodology ${ }^{20,21}$. Seven domains, which were likely to contribute to material bias in the context of this review, were assessed (Figure 2).

\section{Data synthesis and analysis}

The reported statistic was extracted for each study. Statistics for outcomes of interest were calculated when there was sufficient data provided. The effect size (Cohen's d) for outcomes of interest was calculated. ${ }^{22,23}$ For a successful intervention the treatment group needed to show a reduction in the quantity of alcohol consumed (amount/time), frequency of alcohol consumption (drinking events/time), number of binge drinking occasions, AUDIT score or ED representation when compared to the control group. In this context, a negative effect size indicates the intervention is superior to the control while a positive effect size reflects the lack of efficacy of the intervention. A summary of outcomes is reported in Table 3. In addition, the occurrence of 'assessment reactivity' was described. 'Assessment reactivity' occurs when in the process of administering an alcohol assessment, a reduction in patient drinking occurs.

An overall effect size estimate and formal meta-analysis could not be carried out due to the heterogeneity of the studies, population, interventions and outcome measures. A narrative synthesis of the findings from the included studies, structured around the type of intervention, target population characteristics, type of outcome and intervention content is provided.

\section{Results \\ Selected studies}

Search results are summarised in Figure 1. Nineteen papers representing 13 studies met our inclusion criteria. These studies published between 2006 and 2012 included twelve randomised controlled trials and one quasi-randomised trial. Nine studies were single centre and four studies were multi centre including one cluster RCT. Conducted between 1999 and 2010 in the USA, Australia, Germany, Sweden and the United Kingdom, studies ranged in length from one month to four years with up to 12 months follow-up.

Table 2 outlines key characteristics and summary outcome results. Two studies 24,25 reported on presentations with alcohol related injury while eleven studies reported on any emergency department presentation. All participants were screened for alcohol use by either questionnaire or laboratory testing.

An ultra-BI intervention was present in six studies with a face-to-face interaction of 10 minutes or less ${ }^{24,26-30}$, three with a computer intervention ${ }^{25,31,32}$, two with a mobile phone intervention $^{33,34}$ and two that provided a pamphlet only. ${ }^{35,36}$ Eleven studies assessed change in quantity of alcohol consumed and one study assessed change in frequency of alcohol use. Nine studies assessed binge drinking. AUDIT score and return visits to the emergency department were each assessed in two studies. Outcomes were variously measured at six weeks, three months, six months and 12 months.

\section{Methodological quality and risk of bias}


Of the 13 included studies, one was described as a pilot and five lacked sufficient power to show an effect due to small sample 27,32 size or large loss to follow up which ranged from $20 \%$ to $50 \%$. $25-27,32,35$

A summary of the methodological quality and overall risk of bias in the included studies is included in Figure 2. Generally, the risk of bias was low. Incomplete outcome data and failure to blind outcome assessment were the most common risks to bias identified.

\section{Outcomes}

\section{Quantity of alcohol consumed}

Six studies showed a significant reduction in the quantity of alcohol consumed (Table 3 ). Blow et al. ${ }^{24}$ provided computer generated customised or generic printed feedback with or without brief advice reinforcing the feedback to injured patients. Patients receiving brief advice significantly reduced their average consumption during the 12 months of the study compared to the no advice group. There was no difference between tailored or generic advice. For the comparison between tailored feedback with advice and tailored feedback with no advice a small positive effect size at three months $(\mathrm{d}=0.16)$ changed to a small negative effect size at 12 months $(d=-0.18)$. D'Onofrio et al. ${ }^{28}$ randomised patients to a brief negotiated interview (BNI) conducted by trained ED staff, with or without a telephone booster at one month or standard care. A significant treatment effect was shown at 12 months with both BNI and BNI plus booster groups consuming significantly fewer drinks per week than the standard care group. BNI compared with standard care showed a small effect size ( $d=-0.15)$. Havard et al. ${ }^{35}$ showed significant reduction in number of drinks per week at six weeks following a mail-out with feedback after attending ED and screening for risky alcohol use. No data was provided for calculation of effect size. Neumann et al. ${ }^{25}$ provided customised, computer-generated feedback to injured patients with high risk or hazardous drinking attending ED. High risk drinking patients showed a significant reduction in average weekly consumption and a small effect size $(d=-0.19)$ at six months which persisted at 12 months $(\mathrm{d}=-\mathbf{0} .11)$. Hazardous drinking patients showed a significant reduction in daily alcohol intake at 12 months compared with the control group. No data was available for calculation of effect size. In a small pilot study, Suffoletto et al. ${ }^{33}$, randomised patients with hazardous alcohol use to a personalised weekly text message with generic assessment or personalised feedback with goal setting or control. At three months, the personalised feedback group showed a significant reduction in both number of drinks per drinking day and change in number of drinks per drinking day during the past month. This difference existed between intervention and assessment groups only. Comparison of the intervention group with the control group showed an intermediate effect size $(d=-0.40)$ and comparison of the intervention group with the assessment group showed a large effect size $(\mathrm{d}=-1.10)$. Suffoletto et al. ${ }^{34}$ randomised patients attending the ED with an AUDIT-C score $\geq 3$ for women and $\geq 4$ for men to a text message intervention with or without feedback or control. The text message with feedback group showed a significant reduction in number of drinks per drinking day at three months with a small effect $(d=-0.25)$.

\section{Frequency of alcohol use}

No studies showed a significant reduction in frequency of alcohol use (Table 3).

\section{Binge drinking}


Three studies showed a significant reduction in binge drinking (Table 3). D'Onofrio et al. ${ }^{28}$ randomised patients to a brief negotiated interview (BNI) conducted by trained ED staff, with or without a telephone booster at one month or standard care. A significant treatment effect was shown at 12 months with both BNI and BNI plus booster groups having fewer binge drinking days in the past 28 days than the standard care group. BNI compared with standard care showed a small effect size $(d=-0.09)$. In a pilot study, Suffoletto et al. ${ }^{33}$ randomised patients with hazardous alcohol use to a weekly text message with generic assessment or personalised feedback with goal setting or control. At three months, the personalised feedback group showed a significant difference in change in number of heavy drinking days in the past month. However, this difference was between the intervention and assessment group only. Comparison of the intervention group with the control group showed an intermediate effect size $(\mathrm{d}=-0.46)$ while the intervention group compared with the assessment group showed a large effect $(d=-0.95)$. Suffoletto et al. ${ }^{34}$ randomised patients attending the ED with an AUDIT-C score $\geq 3$ for women and $\geq 4$ for men to a text message intervention with or without feedback or control. At three months the text message with feedback group were 2.4 times more likely not to report any binge drinking in the past 30 days than the control group. Comparison of the text message with feedback group with the control group showed a small effect $(d=-0.12)$ while the text message group without feedback compared with the control group showed a small positive effect $(d=0.12)$. The text message with feedback group compared with the text message without feedback showed a small effect size $(\mathrm{d}=-0.22)$.

\section{AUDIT and Emergency Department representation}

Of the four studies that reported on AUDIT and ED representation none showed a significant result (Table 3).

\section{Discussion}

As identified previously in the systematic review by Nilsen et al. ${ }^{37}$ and in our review there were considerable differences across a range of characteristics including the age of patients, screening methods, recruitment eligibility criteria and measurement of alcohol use making a straightforward conclusion difficult.

Our definition of an ultra-BI of less than ten minutes face-to-face time or employing technology such as computers and mobile phones should reduce the previously identified barriers to ED clinician utilisation. ${ }^{7}$ While significant results were shown, no single ultra-BI showed substantial superiority in decreasing the quantity of alcohol consumed.

The age of participants in the included studies ranged from 14 years to 75 years. Two studies included 18-25 year olds, ${ }^{33,34}$ a group identified as the most likely to drink at harmful levels on a single occasion. Similarly, older males are more likely to drink daily, and suffer more chronic health consequences. The prevalence of male participants, up to $79 \%$, in the included studies reflects the higher proportion of males in the at risk drinking population ${ }^{38}$ and their over representation in alcohol ED studies. ${ }^{39}$ This is of relevance as variable treatment effects across different patients have been observed in a number of studies. ${ }^{40}$

The ultra-BIs identified in this review were administered during the ED stay. The timing of an intervention performed following the ED presentation may provide additional benefit, 
particularly in injured patients. Consistent with the concept of 'teachable moment' in ED, an intervention in close proximity to the acute event may promote contemplation. Once the patient has time and capacity to reflect, additional information and prompts may become effective. The addition of a text messages to written information has been shown to be successful. ${ }^{1,34,35}$ Conversely, the provision of a 10 minute phone call one month post ED presentation did not result in a significant difference in outcome when compared with the no phone call group. ${ }^{28}$ Outcome measures and intervals for follow up were also variable. While a significant outcome at 3 months ${ }^{33,34}$ suggests a successful intervention, lack of longer follow-up does not allow for assessment of the maintenance of the effect. Studies with follow up only at 6 or 12 months ${ }^{29,30}$ could fail to see any short-term results of the intervention. This observed maximum short-term effect from a brief intervention is well established in the literature. Such a short-term benefit has the potential for significant health improvement and cost saving.

Although the value of ultra-BI in ED has been hypothesised in the research setting, there have been limits to translating these findings to the clinical setting. This barrier is partly explained by competing priorities and time limits within EDs. Included studies compared two interventions often without non-intervention control groups. It was argued in one study that the recognised effectiveness of Bls made a control group unnecessary. ${ }^{24}$ It is also recognised that in the ED setting, where the act of screening in addition to standard care may be considered an intervention, a true non-intervention control group may be impossible. ${ }^{37}$ Studies that utilised existing 'standard care' were as likely to show benefit from an ultra-BI as those with a contrived control group. It is likely that current 'standard care' does not routinely include provision of even a pamphlet to at risk drinkers. ${ }^{7}$ The studies that have used ED clinicians have resulted in a significant loss to follow-up in addition to a high rate of refusal. ${ }^{26-28}$ In contrast, when research assistants performed the intervention follow-up rates approached $80 \% .{ }^{24,31,33-35}$

Several of the studies included in our review tested the effect of 'assessment reactivity'. Determination of this was complicated by the heterogeneous assessment methods. However, the studies in our review did not identify this as a phenomenon. ${ }^{28,33,34}$ This contrasts with a systematic review by McCambridge et. al. ${ }^{41}$ which found a small effect as a result of asking questions on drinking in Bls across a number of health settings. ED questioning may be different in the pragmatic setting where intoxication, pain and other acute distractions are more likely to be present.

Screening for risky alcohol use by ED patients, administering an ultra-BI, in person or by technological means with provision of patient advice at discharge results in a small reduction in quantity of alcohol consumed at 6 weeks to 12 months. The clinical significance is small. There is no consistent evidence of any reduction in binge drinking and no effect of reducing presentations to ED. With large numbers of adults attending EDs each year an intervention with limited effectiveness may have the potential to affect many people if administered routinely. The potential benefits achievable from harnessing technology by using a computer or telephone text message with minimal resources from within ED could be considerable, but this warrants further research.

Despite broad support for public health and health promotion in ED, ${ }^{7}$ given the limited proven effectiveness and barriers to implementation, it appears to be a low priority for ED clinicians to perform an ultra-BI targeted at alcohol use. This review highlights the lack of any strong evidence for recommending a specific ultra-BI. Future research should focus on 
identifying the most acceptable and workable ultra-BIs for patients and staff in the ED, using a standardised study protocol. Consensus in future research regarding the choice of outcomes, measurement and timeframes, would help us understand the true effects of future interventions. ${ }^{42}$

\section{Limitations}

A single reviewer conducted the search and assessed the eligibility of retrieved papers by screening the titles and abstracts for relevance. Publication bias was not assessed. The search of multiple sources may have reduced this but it cannot be excluded. We have included four studies from two groups of authors. The studies by D'Onofrio $2008^{29}$ and D'Onofrio $2012^{28}$ are distinct studies with different dates and separate analyses. The study by Suffoletto $2012^{33}$ is a pilot study precursor to Suffoletto $2014{ }^{34}$ but is a distinct study with different dates and separate analysis. Self-report of alcohol consumption is a limitation by itself and raises concerns about recall and social desirability responses with the tendency for patients to want to please investigators by reporting more effect in the more intense intervention group.

\section{Conclusions}

The use of an ultra-BI in the ED has some effectiveness in reducing alcohol use in the shortterm. Given the small number and moderate quality of these studies, further research is warranted. With the large number of people attending EDs with risky drinking, finding an effective ultra-BI would have the potential to have a measurable population effect.

Providing clinicians with a simple standardised screening and ultra-BI tool is likely to be of benefit to some of these patients.

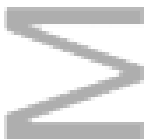

\section{Acknowledgements}

The authors would like to thank Lorena Romero, librarian at the lan Potter Library, Alfred Hospital Melbourne, for her contribution to the identification of information sources and the database search.

This study was funded by a grant from the Australasian College for Emergency Medicine.

\section{Competing interests}

DEW is a section editor for Emergency Medicine Australasia. 


\section{References}

1. World Health Organisation. Global status report on alcohol and health. Geneva: WHO Press; 2014.

2. Trinks A, Festin K, Bendtsen P, Nilsen P. What makes emergency department patients reduce their alcohol consumption?--a computer-based intervention study in Sweden. International emergency nursing. 2013; 21: 3-9.

3. Egerton-Warburton D, Gosbell A, Wadsworth A, Fatovich DM, Richardson DB. Survey of alcohol-related presentations to Australasian emergency departments. The Medical journal of Australia. 2014; 201: 584-7.

4. Walton MA, Goldstein AL, Chermack ST, McCammon RJ, Cunningham RM, Barry KL, et al. Brief alcohol intervention in the emergency department: moderators of effectiveness. Journal of studies on alcohol and drugs. 2008; 69: 550-60.

5. World Health Organisation. Alcohol and injuries: emergency department studies in an international perspective. Geneva, Switzerland: World Health Organisation; 2009 [Cited 12 May

2015]. Available from: http://www.who.int/substance abuse/msbalcinuries.pdf?ua=1.

6. Gentilello LM. Alcohol and injury: American College of Surgeons Committee on trauma requirements for trauma center intervention. J Trauma. 2007; 62: S44-5.

7. Egerton-Warburton D, Gosbell A, Moore K, Jelinek GA. Public health in Australasian emergency departments: Attitudes, barriers and current practices. Emerg Med Australas. 2015. 8. O'Donnell A, Wallace P, Kaner E. From efficacy to effectiveness and beyond: what next for brief interventions in primary care? Frontiers in psychiatry. 2014; 5: 113.

9. Havard A, Shakeshaft A, Sanson-Fisher R. Systematic review and meta-analyses of strategies targeting alcohol problems in emergency departments: interventions reduce alcohol-related injuries. Addiction (Abingdon, England). 2008; 103: 368-76; discussion 77-8.

10. Cunningham JA, Neighbors C, Wild C, Humphreys K. Ultra-brief intervention for problem drinkers: results from a randomized controlled trial. PloS one. 2012; 7: e48003.

11. Australian Institute of Health and Welfare. Australian hospital statistics 2013-14: Emergency department care. Health services series no. 58. Canberra: AlHW; 2014 [Cited 23 June 2015]. Available from: http://www.aihw.gov.au/publication-detail/?id=60129549039.

12. New Zealand Ministry of Health. Emergency Department Use 2011/12: Key findings of the New Zealand Health Survey. Wellington: Ministry of Health. Wellington: Ministry of Health; 2013 [Cited 23 June 2015]. Available from: http://www.health.govt.nz/publication/emergencydepartment-use-2011-12.

13. Delgado M, Ginde AA, Pallin DJ, Camargo CA. Multicenter study of preferences for health education in the emergency department population. Academic Emergency Medicine. 2010; 17: 6528.

14. Glasgow RE, Vogt TM, Boles S, M. Evaluating the public health impact of health promotion interventions: the RE-AIM framework. Am J Public Health. 1999; 89: 1322-7.

15. Liberati A, Altman DG, Tetzlaff J, Mulrow C, Gotzsche PC, loannidis JP, et al. The PRISMA statement for reporting systematic reviews and meta-analyses of studies that evaluate health care interventions: explanation and elaboration. Journal of clinical epidemiology. 2009; 62: e1-34.

16. Higgins JPT, Green S. Cochrane Handbook for Systematic Reviews of Interventions Version 5.1.0 [updated March 2011]. The Cochrane Collaboration; 2011 [Cited 24 November 2014]. Available from: www.cochrane-handbook.org.

17. McGinnes R, Egerton-Warburton D, Hutton J, Fatovich D. Emergency department based preventive health interventions targeting alcohol problems. PROSPERO 2014:CRD42014015322. PROSPERO 2014:CRD42014015322; 2014 [Cited]. Available from:

http://www.crd.york.ac.uk/PROSPERO/display record.asp?ID=CRD42014015322.

This article is protected by copyright. All rights reserved. 
18. National Health and Medical Research Council (NMHRC). How to Review the Evidence: Systematic Identification and Review of the Scientific Literature. Canberra: 1999 [Cited]. Available from: http://www.nhmrc.gov.au/ files nhmrc/publications/attachments/cp65.pdf.

19. Morello RT, Lowthian JA, Barker AL, McGinnes R, Dunt D, Brand C. Strategies for improving patient safety culture in hospitals: a systematic review. BMJ quality \& safety. 2013; 22: 11-8.

20. Higgins JPT, Green S. Cochrane Handbook for Systematic Reviews of Interventions: Cochrane Collaboration; 2011. Available from: www.cochrane-handbook.org. .

21. Ryan R, Hill S, Prictor M, McKenzie J. Cochrane Consumers and Communication Review Group. Study Quality Guide. May 20132013 [Cited 27 April 2015]. Available from:

http://cccrg.cochrane.org/authorresources.

22. Coe R. Effect Size Calculator 2015 [Cited May 2015]. Available from:

http://www.cem.org/effect-size-calculator.

23. Lenhard W, Lenhard A. Calculation of Effect Sizes. Bibergau (Germany): Psychometrica; 2015 [Cited May 2015]. Available from: http://www.psychometrica.de/effect size.html.

24. Blow FC, Barry KL, Walton MA, Maio RF, Chermack ST, Bingham CR, et al. The efficacy of two brief intervention strategies among injured, at-risk drinkers in the emergency department: impact of tailored messaging and brief advice. Journal of Studies on Alcohol,. 2006; 67: 568-78.

25. Neumann T, Neuner B, Weiss-Gerlach E, Tonnesen H, Gentilello LM, Wernecke KD, et al. The effect of computerized tailored brief advice on at-risk drinking in subcritically injured trauma patients. J Trauma. 2006; 61: 805-14.

26. Dent AW, Weiland TJ, Phillips GA, Lee NK. Opportunistic screening and clinician-delivered brief intervention for high-risk alcohol use among emergency department attendees: a randomized controlled trial. Emerg Med Australas. 2008; 20: 121-8.

27. Desy PM, Howard PK, Perhats C, Li S. Alcohol screening, brief intervention, and referral to treatment conducted by emergency nurses: an impact evaluation. J Emerg Nurs. 2010; 36: 538-45.

28. D'Onofrio G, Fiellin DA, Pantalon MV, Chawarski MC, Owens PH, Degutis LC, et al. A brief intervention reduces hazardous and harmful drinking in emergency department patients. Annals of emergency medicine. 2012; 60: 181-92.

29. D'Onofrio G, Pantalon MV, Degutis LC, Fiellin DA, Busch SH, Chawarski MC, et al. Brief intervention for hazardous and harmful drinkers in the emergency department. Annals of emergency medicine. 2008; 51: 742-50.e2.

30. Drummond C, Deluca P, Coulton S, Bland M, Cassidy P, Crawford M, et al. The effectiveness of alcohol screening and brief intervention in emergency departments: A multicentre pragmatic cluster randomized controlled trial. PloS one. 2014; 9.

31. Cunningham RM, Chermack ST, Zimmerman MA, Shope JT, Bingham CR, Blow FC, et al. Brief motivational interviewing intervention for peer violence and alcohol use in teens: one-year followup. Pediatrics. 2012; 129: 1083-90.

32. Trinks A, Festin K, Bendtsen P, Nilsen P. Reach and effectiveness of a computer-based alcohol intervention in a Swedish emergency room. International emergency nursing. 2010; 18: 13846.

33. Suffoletto B, Callaway C, Kristan J, Kraemer K, Clark DB. Text-message-based drinking assessments and brief interventions for young adults discharged from the emergency department. Alcohol Clin Exp Res. 2012; 36: 552-60.

34. Suffoletto B, Kristan J, Callaway C, Kim KH, Chung T, Monti PM, et al. A text message alcohol intervention for young adult emergency department patients: A randomized clinical trial. Annals of emergency medicine. 2014; 64: 664-72.

35. Havard A, Shakeshaft AP, Conigrave KM, Doran CM. Randomized controlled trial of mailed personalized feedback for problem drinkers in the emergency department: the short-term impact. Alcoholism, clinical and experimental research. 2012; 36: 523-31. 
36. Wang TC, Kyriacou DN, Wolf MS. Effects of an intervention brochure on emergency department patients' safe alcohol use and knowledge. Journal of Emergency Medicine. 2010; 39: 561-8.

37. Nilsen P, Baird J, Mello MJ, Nirenberg T, Woolard R, Bendtsen P, et al. A systematic review of emergency care brief alcohol interventions for injury patients. J Subst Abuse Treat. 2008; 35: 184201.

38. Australian Institute of Health and Welfare. National Drug Strategy Household Survey detailed report 2013. Canberra, Australia: Australian Institute of Health and Welfare; 2014 [Cited 201512 May ]. No28. Vatno.PHE183:[Available from.

39. Elzerbi C, Donoghue K, Drummond C. A comparison of the efficacy of brief interventions to reduce hazardous and harmful alcohol consumption between European and non-European countries: a systematic review and meta-analysis of randomised controlled trials. Addiction (Abingdon, England). 2015.

40. Forsythe M, Lee GA. The evidence for implementing alcohol screening and intervention in the emergency department - time to act. International emergency nursing. 2012; 20: 167-72.

41. McCambridge J, Kypri K. Can simply answering research questions change behaviour? Systematic review and meta analyses of brief alcohol intervention trials. PloS one. 2011; 6: e23748.

42. Lowthian JA, McGinnes RA, Brand CA, Barker AL, Cameron PA. Discharging older patients from the emergency department effectively: a systematic review and meta-analysis. Age and ageing. 2015; 44: 761-70.

43. Walton MA, Goldstein AL, Chermack ST, McCammon RJ, Cunningham RM, Barry KL, et al. Brief alcohol intervention in the emergency department: moderators of effectiveness. J Stud Alcohol. 2008; 69: 550-60.

44. Blow FC, Ilgen MA, Walton MA, Czyz EK, McCammon R, Chermack ST, et al. Severity of baseline alcohol use as a moderator of brief interventions in the emergency department. Alcohol Alcohol. 2009; 44: 486-90.

45. Walton MA, Chermack ST, Shope JT, Bingham CR, Zimmerman MA, Blow FC, et al. Effects of a brief intervention for reducing violence and alcohol misuse among adolescents: a randomized controlled trial. JAMA. 2010; 304: 527-35.

46. Cunningham RM, Walton MA, Goldstein A, Chermack ST, Shope JT, Bingham CR, et al. Threemonth follow-up of brief computerized and therapist interventions for alcohol and violence among teens. Academic Emergency Medicine. 2009; 16: 1193-207.

47. Coulton S, Perryman K, Bland M, Cassidy P, Crawford M, Deluca P, et al. Screening and brief interventions for hazardous alcohol use in accident and emergency departments: a randomised controlled trial protocol. BMC Health Serv Res. 2009; 9: 114.

48. Suffoletto B, Callaway CW, Kristan J, Monti P, Clark DB. Mobile phone text message intervention to reduce binge drinking among young adults: study protocol for a randomized controlled trial. Trials. 2013; 14: 93.

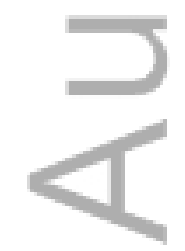


Database: Ovid MEDLINE(R) 1946 to Present with Daily Update Search Strategy:

1 exp Emergencies/ (34380)

2 exp Emergency Medical Services/ (97665)

3 exp Emergency Service, Hospital/ (50876)

4 exp Emergency Treatment/ (94705)

5 exp Emergency Nursing/ (5772)

6 Emergency Medicine/ (10052)

7 (emergency or emergencies).mp. (211074)

81 or 2 or 3 or 4 or 5 or 6 or 7 (293375)

9 exp Alcohol Drinking/ (52041)

10 exp Alcohol-Related Disorders/ (96990)

11 exp Alcoholic Beverages/ (14396)

12 ((excessive* or risk* or heavy or binge or hazard* or problem* or harm* or behavior* or behaviour*) adj4 (drink* or drank* or drunk*)).tw. (19095)

13 (liquor* or intoxicat* or beer or wine or spirits or alcohol* or drunke?ness or inebriat*).tw. (262528)

149 or 10 or 11 or 12 or 13 (302494)

15 exp Alcohol Drinking/pc, th (3686)

16 Alcoholic Intoxication/pc, th (1215)

17 Alcohol-Related Disorders/pc, th (818)

18 Alcoholism/pc, th (10893)

1915 or 16 or 17 or $18(15301)$

208 and 19 (558)

218 and 14 (6498)

2220 or 21 (6498)

23 limit 22 to $y r=" 1996-2015 "$ (4559)

24 (study or studies).mp,pt. (7565216)

2523 and 24 (2682)

26 limit 25 to ("review" or systematic reviews) (190)

2725 not 26 (2492)

28 limit 27 to ("all infant (birth to 23 months)" or "newborn infant (birth to 1 month)" or "infant (1 to 23 months)" or "preschool child (2 to 5 years)") (199)

2927 not $28(2293)$

This article is protected by copyright. All rights reserved. 
Table $2 \bigcirc$ Characteristics of included studies investigating ultra-Bls for alcohol harm in the ED

$m=$

\begin{tabular}{|c|c|c|c|c|c|c|c|c|}
\hline $\begin{array}{l}\text { Author } \\
\text { Year }\end{array}$ & $\begin{array}{l}\text { Setting } \\
\text { Population }\end{array}$ & $\begin{array}{l}\text { Study design, } \\
\text { Length } \\
\text { Years }\end{array}$ & $\begin{array}{l}\text { Sample size } \\
\text { (Total/ } \\
\text { Intervention/ } \\
\text { Control) }\end{array}$ & $\begin{array}{l}\text { Number } \\
\text { screened }\end{array}$ & $\begin{array}{l}\text { Intervention details } \\
\text { Duration }\end{array}$ & $\begin{array}{l}\text { Intervention } \\
\text { delivery }\end{array}$ & $\begin{array}{l}\text { Control / } \\
\text { Comparison }\end{array}$ & $\begin{array}{l}\text { Assessment } \\
\text { reactivity } \\
\text { effect found }\end{array}$ \\
\hline $\begin{array}{l}\text { Blow et al., } \\
2006^{24} \\
\text { Walton et al., } \\
2008^{43} \\
\text { Blow et al., } \\
2009^{44}\end{array}$ & $\begin{array}{l}\text { USA } \\
\geq 19 \text { yrs } \\
\text { Male } 71 \% \\
\text { Admitted and non- } \\
\text { admitted } \\
\text { Single centre } \\
\text { Injured patients }\end{array}$ & $\begin{array}{l}\text { RCT } \\
2.5 \text { years } \\
1999-2002\end{array}$ & $\begin{array}{l}494 / 129 \\
\text { Tailored + } \\
\text { advice/ } 121 \\
\text { Tailored / } 124 \\
\text { Generic + } \\
\text { advice/ } 120 \\
\text { Generic }\end{array}$ & 4,476 & $\begin{array}{l}\text { Computer health } \\
\text { survey. } \\
\text { Reviewed booklet } \\
\text { and motivational } \\
\text { interviewing } \\
\text { Time not stated }\end{array}$ & $\begin{array}{l}\text { Research social } \\
\text { workers }\end{array}$ & $\begin{array}{l}\text { Told at risk, } \\
\text { booklet, alcohol } \\
\text { use } \\
\text { consequences. } \\
\text { Tailored or } \\
\text { generic }\end{array}$ & $\mathrm{N} / \mathrm{A}$ \\
\hline $\begin{array}{l}\text { Cunningham et al., } \\
2012^{31} \\
\text { Walton et al., } \\
2010^{45} \\
\text { Cunningham et al., } \\
2009^{46}\end{array}$ & $\begin{array}{l}\text { USA } \\
14-18 \text { yrs } \\
\text { Male } 44 \% \\
\text { Single centre } \\
\text { All patients }\end{array}$ & $\begin{array}{l}\text { RCT } \\
36 \text { mths } \\
2006-2009\end{array}$ & $\begin{array}{l}726 / \mathrm{TBI} 254 / \\
\text { CBI 237/ control } \\
235\end{array}$ & 3,338 & $\begin{array}{l}\text { Therapist with } \\
\text { computer assistance } \\
\text { (TBI) } 37 \text { mins } \\
\text { Computer alone (CBI) } \\
29 \mathrm{mi}\end{array}$ & $\begin{array}{l}\text { Research Assistant } \\
\text { and computer }\end{array}$ & $\begin{array}{l}\text { Brochure and } \\
\text { phone numbers } \\
\text { for community } \\
\text { organisations }\end{array}$ & $\mathrm{N} / \mathrm{A}$ \\
\hline $\begin{array}{l}\text { D'Onofrio et al., } \\
2008^{29}\end{array}$ & $\begin{array}{l}\text { USA } \\
\geq 18 \text { yrs } \\
\text { Male } 68 \% \\
\text { Single Centre } \\
\text { All patients }\end{array}$ & $\begin{array}{l}\text { RCT } \\
2.5 \text { years } \\
2002-2004\end{array}$ & $500 / 250 / 250$ & 16,182 & $\begin{array}{l}\text { Brief Negotiation } \\
\text { Interview (BNI) } \\
\text { 5-10 mins }\end{array}$ & $\begin{array}{l}\text { Physicians } \\
\text { Residents } \\
\text { Physician } \\
\text { Associates }\end{array}$ & $\begin{array}{l}\text { Control-scripted } \\
\text { discharge } \\
\text { Instructions (DI) } \\
<1 \text { min instruction } \\
\text { around harmful } \\
\text { drinking and } \\
\text { brochure. }\end{array}$ & N/A \\
\hline $\begin{array}{l}\text { D'Onofrio et al., } \\
2012^{28}\end{array}$ & $\begin{array}{l}\text { USA } \\
>18 \text { yrs } \\
\text { Male } 72 \% \\
\text { Single centre } \\
\text { Urban ED }\end{array}$ & $\begin{array}{l}\text { RCT } \\
4 \text { years } \\
2005-2009\end{array}$ & $889 / 740 / 148$ & 33,810 & $\begin{array}{l}\text { Brief Negotiation } \\
\text { Interview (BNI) } \\
\text { Mean } 7 \text { mins } \\
\text { Booster mean } 10 \\
\text { mins }\end{array}$ & $\begin{array}{l}\text { Emergency } \\
\text { Physicians, } \\
\text { Residents, } \\
\text { Physician } \\
\text { Associates, Nurses }\end{array}$ & $\begin{array}{l}\text { Standard care } \\
\text { (SC) }\end{array}$ & No \\
\hline
\end{tabular}

Ultra-Brief Interventions in the Emergency Department

This article is protected by copyright. All rights reserved. 


\begin{tabular}{|c|c|c|c|c|c|c|c|c|}
\hline $\begin{array}{l}\text { Author } \\
\text { Year }\end{array}$ & $\begin{array}{l}\text { Setting } \\
\text { Population }\end{array}$ & $\begin{array}{l}\text { Study design, } \\
\text { Length } \\
\text { Years }\end{array}$ & $\begin{array}{l}\text { Sample size } \\
\text { (Total/ } \\
\text { Intervention/ } \\
\text { Control) }\end{array}$ & $\begin{array}{l}\text { Number } \\
\text { screened }\end{array}$ & $\begin{array}{l}\text { Intervention details } \\
\text { Duration }\end{array}$ & $\begin{array}{l}\text { Intervention } \\
\text { delivery }\end{array}$ & $\begin{array}{l}\text { Control / } \\
\text { Comparison }\end{array}$ & $\begin{array}{l}\text { Assessment } \\
\text { reactivity } \\
\text { effect found }\end{array}$ \\
\hline & All patients & & & & & $\begin{array}{l}\text { Booster: trained } \\
\text { primary care nurse }\end{array}$ & & \\
\hline $\begin{array}{l}\text { Dent et al., } \\
2008^{26}\end{array}$ & $\begin{array}{l}\text { Australia } \\
\geq 18 \text { yrs } \\
\text { Male } 78 \% \\
\text { Single centre, } \\
\text { Urban ED } \\
\text { All patients }\end{array}$ & $\begin{array}{l}\text { RCT } \\
2004-2005 \\
1 \text { year }\end{array}$ & $\begin{array}{l}468 / \mathrm{BI} 148 / \mathrm{MI} \\
159 / 161\end{array}$ & 10,274 & $\begin{array}{l}\text { BI } 5 \text { minutes / } \\
\text { Motivational } \\
\text { Intervention (MI) } \\
\text { offsite } 45 \text { mins }\end{array}$ & $\begin{array}{l}\text { ED staff - nurses } \\
\text { and doctors }\end{array}$ & $\begin{array}{l}\text { Standard care } \\
\text { (SC) }\end{array}$ & $\mathrm{N} / \mathrm{A}$ \\
\hline $\begin{array}{l}\text { Desy et al., } \\
2010^{27}\end{array}$ & $\begin{array}{l}\text { USA } \\
\geq 18 y r s \\
\text { M } 60 \% \\
\text { Single Centre } \\
\text { All patients }\end{array}$ & $\begin{array}{l}\text { RCT } \\
16 \text { months } \\
2006-2007\end{array}$ & $91 / 49 / 42$ & 15,891 & $\begin{array}{l}\text { MI 5-10 mins } \\
\text { Educational } \\
\text { brochures } \\
\text { Local resources }\end{array}$ & Staff nurses & $\begin{array}{l}\text { Referral to } \\
\text { community } \\
\text { resources. }\end{array}$ & N/A \\
\hline $\begin{array}{l}\text { Drummond et al., } \\
2014{ }^{30} \\
\text { Coulton et al., } \\
2009^{47}\end{array}$ & $\begin{array}{l}\text { UK } \\
\geq 18 y r s \\
9 \text { Centres } \\
\text { M 65\% } \\
\text { All patients }\end{array}$ & $\begin{array}{l}\text { RCT Cluster } \\
14 \text { months } \\
2008-2010\end{array}$ & $\begin{array}{l}\text { 1204/PIL } \\
\text { 406/BA 403/ } \\
\text { BLC } 395\end{array}$ & 3,737 & $\begin{array}{l}\text { Patient Information } \\
\text { Leaflet (PIL), } \\
\text { Brief Advice (BA) } \\
<5 \text { mins, } \\
\text { Brief Lifestyle } \\
\text { Counselling (BLC) } 20 \\
\text { mins }\end{array}$ & $\begin{array}{l}\text { ED staff } \\
\text { Research staff } \\
\text { when ED pick up } \\
\text { low. } \\
\text { Drug \& Alcohol } \\
\text { worker for BLC }\end{array}$ & $\begin{array}{l}\text { Scripted } \\
\text { discharge advice } \\
\text { about hazardous } \\
\text { drinking. } \\
\text { Handout. }\end{array}$ & $\mathrm{N} / \mathrm{A}$ \\
\hline $\begin{array}{l}\text { Havard et al., } \\
2012^{35}\end{array}$ & $\begin{array}{l}\text { Australia } \\
\geq 18 y r s \\
14 \text { yrs } \\
\text { M 74\% } \\
5 \text { rural EDs } \\
\text { All patients }\end{array}$ & $\begin{array}{l}\text { RCT } \\
9 \text { months } \\
2009\end{array}$ & $304 / 150 / 154$ & 1,415 & $\begin{array}{l}\text { Mailed pamphlet } \\
\text { with normative } \\
\text { feedback and } \\
\text { strategies. }\end{array}$ & Research Assistant & $\begin{array}{l}\text { Assessment only. } \\
\text { No feedback }\end{array}$ & $\mathrm{N} / \mathrm{A}$ \\
\hline $\begin{array}{l}\text { Neumann et al., } \\
2006^{25}\end{array}$ & $\begin{array}{l}\text { Germany } \\
\geq 18 y r s\end{array}$ & $\begin{array}{l}\text { RCT } \\
14 \text { months }\end{array}$ & $1139 / 561 / 575$ & 3,026 & $\begin{array}{l}\text { Computer generated } \\
\text { written feedback }\end{array}$ & $\begin{array}{l}\text { Research Assistant } \\
\text { / computer }\end{array}$ & $\begin{array}{l}\text { Routine } \\
\text { emergency }\end{array}$ & N/A \\
\hline
\end{tabular}

Ultra-Brief Interventions in the Emergency Department

This article is protected by copyright. All rights reserved. 


\begin{tabular}{|c|c|c|c|c|c|c|c|c|}
\hline $\begin{array}{l}\text { Author } \\
\text { Year }\end{array}$ & $\begin{array}{l}\text { Setting } \\
\text { Population }\end{array}$ & $\begin{array}{l}\text { Study design, } \\
\text { Length } \\
\text { Years }\end{array}$ & $\begin{array}{l}\text { Sample size } \\
\text { (Total/ } \\
\text { Intervention/ } \\
\text { Control) }\end{array}$ & $\begin{array}{l}\text { Number } \\
\text { screened }\end{array}$ & $\begin{array}{l}\text { Intervention details } \\
\text { Duration }\end{array}$ & $\begin{array}{l}\text { Intervention } \\
\text { delivery }\end{array}$ & $\begin{array}{l}\text { Control / } \\
\text { Comparison }\end{array}$ & $\begin{array}{l}\text { Assessment } \\
\text { reactivity } \\
\text { effect found }\end{array}$ \\
\hline 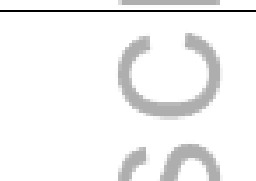 & $\begin{array}{l}\text { Male 79\% } \\
\text { Single centre } \\
\text { Urban ED } \\
\text { Injured patients }\end{array}$ & $2001-2003$ & & & $\begin{array}{l}\text { FRAMES, goals, } \\
\text { personalisation, ref } \\
\text { to treatment services } \\
\text { Time not described }\end{array}$ & & $\begin{array}{l}\text { department } \\
\text { procedures }\end{array}$ & \\
\hline $\begin{array}{l}\text { Suffoletto et al., } \\
2012^{33}\end{array}$ & $\begin{array}{l}\text { USA } \\
18-24 \text { yrs } \\
\text { Male } 36 \% \\
3 \text { Centres } \\
\text { Urban ED } \\
\text { All patients }\end{array}$ & $\begin{array}{l}\text { RCT } \\
1 \text { month } \\
2010\end{array}$ & $\begin{array}{l}\text { 45/15/Assessme } \\
\text { nt 15/ Control } \\
15\end{array}$ & 106 & $\begin{array}{l}\text { Weekly Text Message } \\
\text { based feedback with } \\
\text { goal-setting. } \\
\text { Time not described }\end{array}$ & $\begin{array}{l}\text { Text message (TM) } \\
\text { with feedback }\end{array}$ & $\begin{array}{l}\text { Assessment - TM; } \\
\text { Control - TM with } \\
\text { no assessment }\end{array}$ & No \\
\hline $\begin{array}{l}\text { Suffoletto et al., } \\
2014^{34} \\
\text { Suffoletto et al., } \\
2013^{48}\end{array}$ & $\begin{array}{l}\text { USA } \\
18-25 \text { years } \\
\text { Male } 35 \% \\
4 \text { centres } \\
\text { All patients }\end{array}$ & $\begin{array}{l}\text { RCT } \\
1 \text { year } \\
2012-2013\end{array}$ & $\begin{array}{l}765 / 384 \\
S A+F / 196 \\
S A / 185 \text { control }\end{array}$ & 3,061 & $\begin{array}{l}\text { SA+F =SMS } \\
\text { assessments }+ \\
\text { feedback } \\
\text { SA = SMS } \\
\text { assessments } \\
\text { Time not described }\end{array}$ & $\begin{array}{l}\text { Research Assistant } \\
5 \text { min } \\
\text { computerised } \\
\text { assessment }\end{array}$ & $\begin{array}{l}\text { Local list of } \\
\text { treatment } \\
\text { services, no SMS. }\end{array}$ & No \\
\hline $\begin{array}{l}\text { Trinks et al., } \\
2010^{32}\end{array}$ & $\begin{array}{l}\text { Sweden } \\
18-69 \text { yrs } \\
\text { Male } 61 \% \\
\text { Single Centre } \\
\text { County hospital } \\
\text { All patients }\end{array}$ & $\begin{array}{l}\text { RCT } \\
1 \text { year } \\
2007-2008\end{array}$ & 93/52 LF/41 SF & 1,570 & $\begin{array}{l}\text { Long Feedback (LF) - } \\
\text { Tailored advice and } \\
\text { motivation to change } \\
\text { and traffic light } \\
\text { feedback } \\
\text { 5-10 minutes }\end{array}$ & $\begin{array}{l}\text { Computer in } \\
\text { waiting room }\end{array}$ & $\begin{array}{l}\text { Short Feedback } \\
\text { (SF) - graphic } \\
\text { illustration of risk } \\
\text { levels on } \\
\text { computer }\end{array}$ & N/A \\
\hline $\begin{array}{l}\text { Wang et al., } \\
201036\end{array}$ & $\begin{array}{l}\text { USA } \\
18-75 \text { yrs } \\
\text { Male } 37 \% \\
\text { Single centre } \\
\text { All patients } \\
\text { presenting to ED }\end{array}$ & $\begin{array}{l}\text { Quasi RCT } \\
\text { One Month } \\
2004\end{array}$ & $252 / 125 / 127$ & 277 & $\begin{array}{l}\text { ACEP Alcohol } \\
\text { pamphlet "how much } \\
\text { is too much?" } \\
1 \text { minute }\end{array}$ & One Physician & No pamphlet & No \\
\hline
\end{tabular}

Ultra-Brief Interventions in the Emergency Department

This article is protected by copyright. All rights reserved. 


\begin{tabular}{|c|c|c|c|c|c|c|c|c|}
\hline $\begin{array}{l}\text { Author } \\
\text { Year }\end{array}$ & $\begin{array}{l}\text { Setting } \\
\text { Population }\end{array}$ & $\begin{array}{l}\text { Study design, } \\
\text { Length } \\
\text { Years }\end{array}$ & $\begin{array}{l}\text { Sample size } \\
\text { (Total/ } \\
\text { Intervention/ } \\
\text { Control) }\end{array}$ & $\begin{array}{l}\text { Number } \\
\text { screened }\end{array}$ & $\begin{array}{l}\text { Intervention details } \\
\text { Duration }\end{array}$ & $\begin{array}{l}\text { Intervention } \\
\text { delivery }\end{array}$ & $\begin{array}{l}\text { Control / } \\
\text { Comparison }\end{array}$ & $\begin{array}{l}\text { Assessment } \\
\text { reactivity } \\
\text { effect found }\end{array}$ \\
\hline
\end{tabular}

This article is protected by copyright. All rights reserved. 
Table 3 Summary of outcome results for included ultra-BI studies

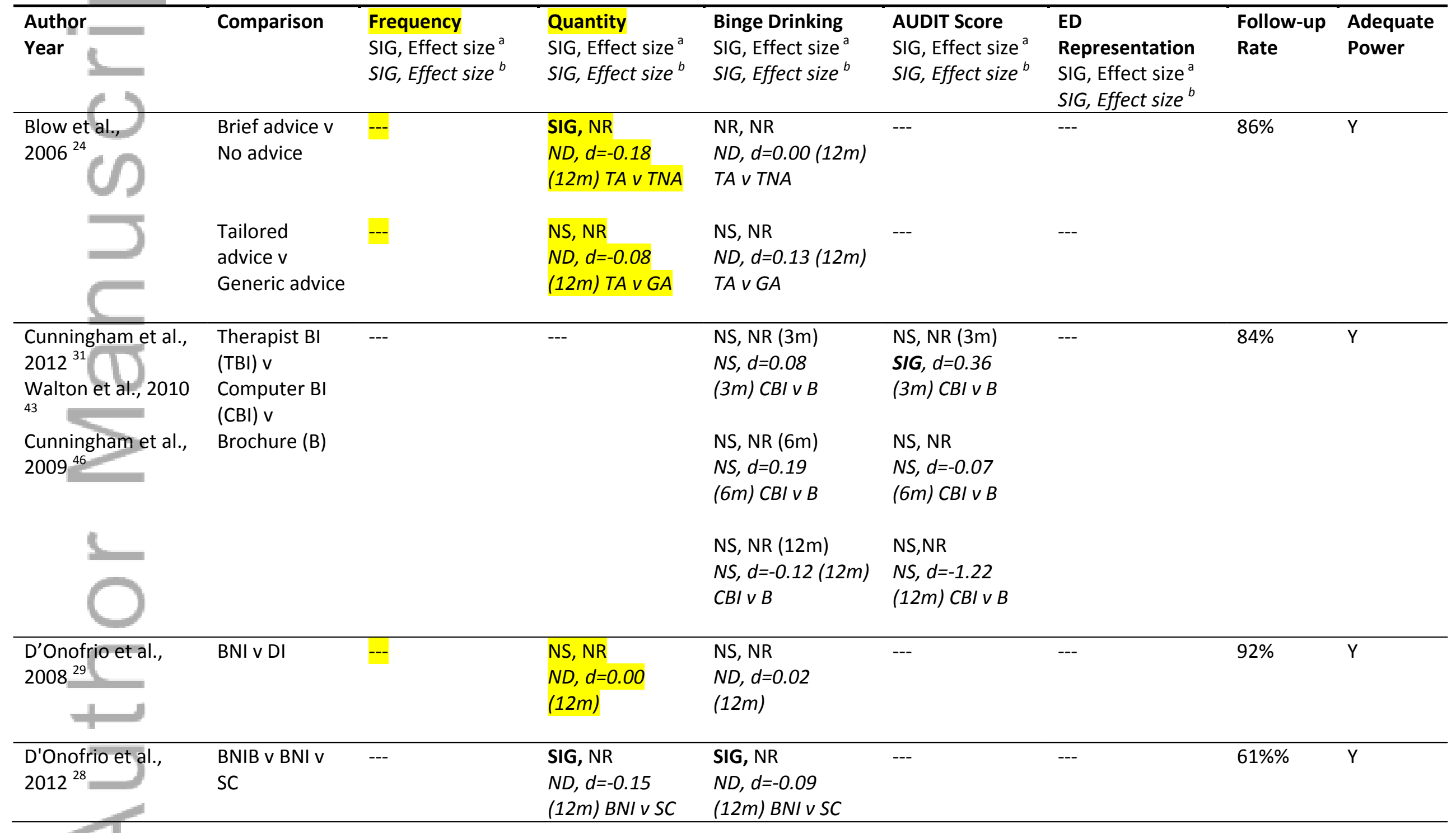




\begin{tabular}{|c|c|c|c|c|c|c|c|c|}
\hline $\begin{array}{l}\text { Author } \\
\text { Year }\end{array}$ & Comparison & $\begin{array}{l}\text { Frequency } \\
\text { SIG, Effect size } \\
\text { SIG, Effect size }\end{array}$ & $\begin{array}{l}\text { Quantity } \\
\text { SIG, Effect size }{ }^{a} \\
\text { SIG, Effect size }\end{array}$ & $\begin{array}{l}\text { Binge Drinking } \\
\text { SIG, Effect size }{ }^{a} \\
\text { SIG, Effect size }\end{array}$ & $\begin{array}{l}\text { AUDIT Score } \\
\text { SIG, Effect size }{ }^{a} \\
\text { SIG, Effect size }\end{array}$ & $\begin{array}{l}\text { ED } \\
\text { Representation } \\
\text { SIG, Effect size } \\
\text { SIG, Effect size }\end{array}$ & $\begin{array}{l}\text { Follow-up } \\
\text { Rate }\end{array}$ & $\begin{array}{l}\text { Adequate } \\
\text { Power }\end{array}$ \\
\hline Dent et al., $2008^{26}$ & $\mathrm{BI} \vee \mathrm{SC}$ & --- & $\begin{array}{l}\mathrm{NS}, \mathrm{NR} \\
\mathrm{ND}, \mathrm{NC}(1 \mathrm{~m}) \\
\mathrm{NS}, \mathrm{NR} \\
\mathrm{ND}, \mathrm{NC}(3 \mathrm{~m})\end{array}$ & --- & --- & $\begin{array}{l}\text { NS, NR } \\
N D, N C(1 m) \\
N S, N R \\
N D, N C(3 m)\end{array}$ & $56 \%$ & $\mathrm{~N}$ \\
\hline $\begin{array}{l}\text { Desy et al., } \\
2010^{27}\end{array}$ & $\begin{array}{l}\text { SBIRT v Usual } \\
\text { care }\end{array}$ & $\begin{array}{l}\mathrm{NS}, \mathrm{NR} \\
\mathrm{ND}, \mathrm{NC} \\
(3 \mathrm{~m})\end{array}$ & $\begin{array}{l}\mathrm{NS}, \mathrm{NR} \\
\mathrm{ND}, \mathrm{NC} \\
(3 \mathrm{~m})\end{array}$ & --- & --- & $\begin{array}{l}\text { NS, NR } \\
N D, d=-0.3(3 \mathrm{~m})\end{array}$ & $51 \%$ & $\mathrm{~N}$ \\
\hline $\begin{array}{l}\text { Drummond et al., } \\
2014{ }^{30}\end{array}$ & $\mathrm{BA} \vee \mathrm{PIL}$ & --- & $\begin{array}{l}\text { NS, NR } \\
N D, N C \\
(6 m) \\
N S, N R \\
N D, N C \\
(12 m)\end{array}$ & --- & $\begin{array}{l}\text { NS, NR } \\
N D, d=0.15 \\
(6 m) \\
N S, N R \\
N D, d=0.14 \\
(12 m)\end{array}$ & --- & $67 \%$ & $Y$ \\
\hline $\begin{array}{l}\text { Havard et } \\
2012^{35}\end{array}$ & $\begin{array}{l}\text { Mailout v } \\
\text { Control }\end{array}$ & --- & $\begin{array}{l}\text { SIG, NR } \\
N D, N C \\
\text { (6 weeks) }\end{array}$ & $\begin{array}{l}\text { NS, NR } \\
N D, N C \\
\text { (6 weeks) }\end{array}$ & --- & --- & $80 \%$ & $\mathrm{~N}$ \\
\hline $\begin{array}{l}\text { Neumann et al., } \\
200625\end{array}$ & $\begin{array}{l}\text { Computer } \\
\text { intervention v } \\
\text { SC }\end{array}$ & --- & $\begin{array}{l}\text { NS, NR } \\
N D, N C \\
(6 m)(g / \text { day }) \\
\text { SIG, NR } \\
N D, N C\end{array}$ & & --- & --- & $58 \%$ & $\mathrm{~N}$ \\
\hline
\end{tabular}




\begin{tabular}{|c|c|c|c|c|c|c|c|c|}
\hline $\begin{array}{l}\text { Author } \\
\text { Year }\end{array}$ & Comparison & $\begin{array}{l}\text { Frequency } \\
\text { SIG, Effect size } \\
\text { SIG, Effect size }\end{array}$ & $\begin{array}{l}\text { Quantity } \\
\text { SIG, Effect size } \\
\text { SIG, Effect size }\end{array}$ & $\begin{array}{l}\text { Binge Drinking } \\
\text { SIG, Effect size } \\
\text { SIG, Effect size }\end{array}$ & $\begin{array}{l}\text { AUDIT Score } \\
\text { SIG, Effect size }{ }^{a} \\
\text { SIG, Effect size }\end{array}$ & $\begin{array}{l}\text { ED } \\
\text { Representation } \\
\text { SIG, Effect size } \\
\text { SIG, Effect size }\end{array}$ & $\begin{array}{l}\text { Follow-up } \\
\text { Rate }\end{array}$ & $\begin{array}{l}\text { Adequate } \\
\text { Power }\end{array}$ \\
\hline 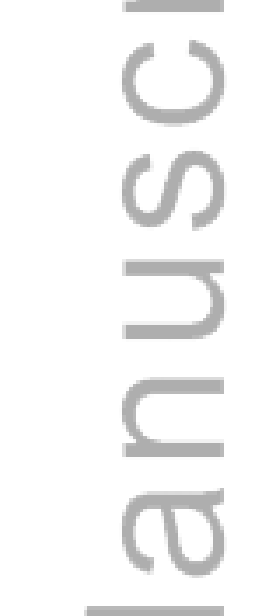 & & --- & $\begin{array}{l}\text { (12m) (g/day) } \\
\text { SIG, NR } \\
\text { SIG, } d=-0.19 \\
\text { (6m) (average } \\
\text { weekly } \\
\text { consumption) } \\
\text { NS, NR } \\
\text { NS, d=-0.11 } \\
\text { (12m) (average } \\
\text { weekly } \\
\text { consumption) }\end{array}$ & & & & & \\
\hline $\begin{array}{l}\text { Suffoletto et al., } \\
2012^{33}\end{array}$ & $\begin{array}{l}\text { SMS } \\
\text { Intervention v } \\
\text { SMS } \\
\text { Assessment v } \\
\text { Control }\end{array}$ & --- & $\begin{array}{l}\text { SIG, NR } \\
N D, d=-0.40 \\
(3 m) S M S I \vee C \\
N D, d=-1.10 \\
(3 m) S M S I \vee A\end{array}$ & $\begin{array}{l}\text { SIG, NR } \\
N D, d=-0.46 \\
(3 m) S M S I \vee C \\
N D, d=-0.95 \\
(3 m) S M S I \vee A\end{array}$ & --- & --- & $87 \%$ & Pilot \\
\hline $\begin{array}{l}\text { Suffoletto et al., } \\
2014^{34}\end{array}$ & $\begin{array}{l}\text { SMSF v SMS v } \\
\text { Control }\end{array}$ & --- & $\begin{array}{l}\text { SIG, NR } \\
N D, d=-0.25 \\
(3 m) \text { SMSF } \vee C \\
N D, d=0.08 \\
(3 m) \text { SMS } \vee C \\
N D, d=-0.34\end{array}$ & $\begin{array}{l}\text { SIG, NR } \\
N D, d=-0.12 \\
(3 m) S M S F \vee C \\
N D, d=0.12 \\
(3 m) S M S \vee C \\
N D, d=-0.22\end{array}$ & --- & --- & $78 \%$ & $\mathrm{Y}$ \\
\hline
\end{tabular}

This article is protected by copyright. All rights reserved. 


\begin{tabular}{|c|c|c|c|c|c|c|c|c|}
\hline $\begin{array}{l}\text { Author } \\
\text { Year }\end{array}$ & Comparison & $\begin{array}{l}\text { Frequency } \\
\text { SIG, Effect size }{ }^{a} \\
\text { SIG, Effect size }\end{array}$ & $\begin{array}{l}\text { Quantity } \\
\text { SIG, Effect size }{ }^{a} \\
\text { SIG, Effect size }\end{array}$ & $\begin{array}{l}\text { Binge Drinking } \\
\text { SIG, Effect size } \\
\text { SIG, Effect size }\end{array}$ & $\begin{array}{l}\text { AUDIT Score } \\
\text { SIG, Effect size }{ }^{a} \\
\text { SIG, Effect size }\end{array}$ & $\begin{array}{l}\text { ED } \\
\text { Representation } \\
\text { SIG, Effect size } \\
\text { SIG, Effect size }\end{array}$ & $\begin{array}{l}\text { Follow-up } \\
\text { Rate }\end{array}$ & $\begin{array}{l}\text { Adequate } \\
\text { Power }\end{array}$ \\
\hline & & & $\begin{array}{l}(3 m) S M S F v \\
S M S\end{array}$ & $(3 m)$ SMSF v SMS & & & & \\
\hline $\begin{array}{l}\text { Trinks et al., } \\
2010^{32}\end{array}$ & $\begin{array}{l}\text { Long Feed } \\
\text { back v Short } \\
\text { Feed back }\end{array}$ & --- & $\begin{array}{l}\mathrm{NS}, \mathrm{NR} \\
N D, N C(6 \mathrm{~m})\end{array}$ & $\begin{array}{l}\mathrm{NS}, \mathrm{NR} \\
N D, N C(6 \mathrm{~m})\end{array}$ & --- & --- & $64 \%$ & $\mathrm{~N}$ \\
\hline $\begin{array}{l}\text { Wang et al., } \\
2010^{36}\end{array}$ & $\begin{array}{l}\text { Pamphlet v No } \\
\text { pamphlet }\end{array}$ & --- & --- & $\begin{array}{l}\mathrm{NS}, \mathrm{NR} \\
N D, N C(1 \mathrm{~m})\end{array}$ & --- & --- & $75 \%$ & $\mathrm{Y}$ \\
\hline
\end{tabular}

a Reported for comparison; b Calculated for comparison of interest; NC effect size not calculable for reported statistic from data available; ND not able to be calculated from data available; NR not reported

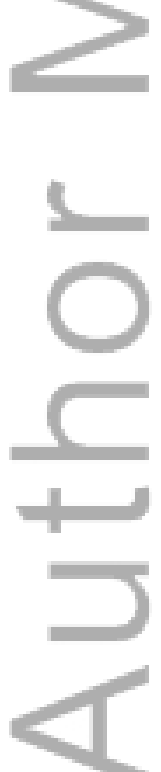

Ultra-Brief Interventions in the Emergency Department

This article is protected by copyright. All rights reserved. 


\section{Figures and Tables}

Figure 1. PRISMA flowchart of search results

Figure 2. Risk of Bias Summary for included ultra-BI studies

Table 1. Search Strategy

Table 2. Characteristics of included studies investigating ultra-Bls for alcohol harm in the ED

Table 3 Summary of outcome results for included ultra-BI studies

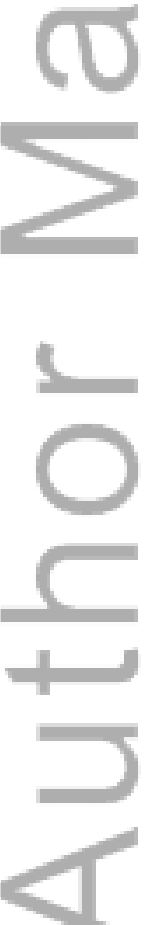

Ultra-Brief Interventions in the Emergency Department 


\section{University Library}

\section{- M M I N E R VA \\ A gateway to Melbourne's research publications}

Minerva Access is the Institutional Repository of The University of Melbourne

Author/s:

McGinnes, RA;Hutton, JE;Weiland, TJ;Fatovich, DM;Egerton-Warburton, D

Title:

Review article: Effectiveness of ultra-brief interventions in the emergency department to reduce alcohol consumption: A systematic review

Date:

2016-12-01

\section{Citation:}

McGinnes, R. A., Hutton, J. E., Weiland, T. J., Fatovich, D. M. \& Egerton-Warburton, D. (2016). Review article: Effectiveness of ultra-brief interventions in the emergency department to reduce alcohol consumption: A systematic review. EMERGENCY MEDICINE AUSTRALASIA, 28 (6), pp.629-640. https://doi.org/10.1111/1742-6723.12624.

Persistent Link:

http://hdl.handle.net/11343/291544 